The INL is a

U.S. Department of Energy

National Laboratory

operated by

Battelle Energy Alliance

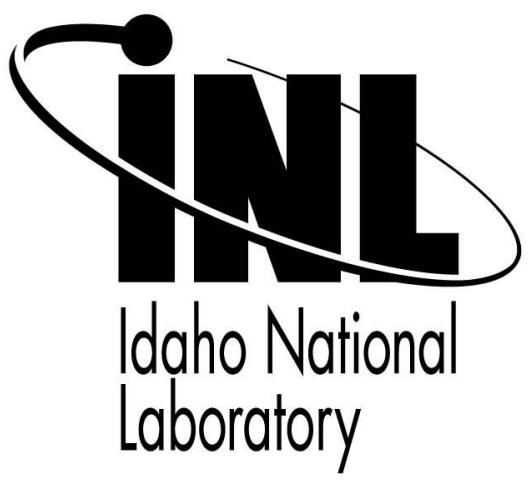

INL/CON-06-11962

PREPRINT

\title{
Tensile Stress-Strain Results for 304L and 316L Stainless Steel Plate at Temperature
}

\section{ASME Pressure Vessels and Piping Division Conference}

\author{
R. K. Blandford \\ D. K. Morton \\ S. D. Snow \\ T. E. Rahl
}

July 2007

This is a preprint of a paper intended for publication in a journal or proceedings. Since changes may be made before publication, this preprint should not be cited or reproduced without permission of the author. This document was prepared as an account of work sponsored by an agency of the United States Government. Neither the United States Government nor any agency thereof, or any of their employees, makes any warranty, expressed or implied, or assumes any legal liability or responsibility for any third party's use, or the results of such use, of any information, apparatus, product or process disclosed in this report, or represents that its use by such third party would not infringe privately owned rights. The views expressed in this paper are not necessarily those of the United States Government or the sponsoring agency. 
PVP2007-26096

\title{
TENSILE STRESS-STRAIN RESULTS FOR 304L AND 316L STAINLESS STEEL ${ }^{1}$ PLATE AT TEMPERATURE
}

\author{
R. K. Blandford \\ D. K. Morton, S. D. Snow, T. E. Rahl \\ Idaho National Laboratory \\ P.O. Box 1625 \\ Idaho Falls, Idaho 83415-3760 \\ United States of America \\ (208) 526-9354, robert.blandford@inl.gov
}

\section{ABSTRACT}

The Idaho National Laboratory is conducting moderate strain rate (5 to 200 per second) research on stainless steel materials in support of the Department of Energy's National Spent Nuclear Fuel Program. For this research, strain rate effects are characterized by comparison to quasi-static tensile test results. Considerable tensile testing has been conducted resulting in the generation of a large amount of basic material data expressed as engineering and true stress-strain curves. The purpose of this paper is to present the results of quasi-static tensile testing of 304L and 316 L stainless steels in order to add to the existing data pool for these materials and make the data more readily available to other researchers, engineers, and interested parties.

Standard tensile testing of round specimens in accordance with ASTM procedure A 370-03a was conducted on 304L and $316 \mathrm{~L}$ stainless steel plate materials at temperatures ranging from $-20^{\circ} \mathrm{F}$ to $600^{\circ} \mathrm{F}$. Two plate thicknesses, eight material heats, and both base and weld metal were tested. Material yield strength, ultimate strength, ultimate strain, fracture strength, fracture strain and reduction in area were determined. Engineering and true stress-strain curves to failure were developed and comparisons to ASME Code minimums were made. The procedures used during testing and the typical results obtained are presented in this paper.

\section{INTRODUCTION}

The Department of Energy's (DOE) National Spent Nuclear Fuel Program (NSNFP), working with the Office of Civilian Radioactive Waste Management (OCRWM), the Idaho National Laboratory (INL) and other DOE sites, has supported development of canisters for loading and interim storage, transportation, and disposal of DOE spent nuclear fuel (SNF). To assess the integrity of these SNF canisters under dynamic, impact loading, the INL is conducting moderate strain rate (5 to 200 per second) research on $304 \mathrm{~L}$ and $316 \mathrm{~L}$ stainless steels which are the preferred materials for construction. The goal of this research is to define and justify elevated strain rate effects for these materials over a range of applicable temperatures and develop corresponding true stress-strain relationships that can be used to perform accurate analytical assessments of canister impact events. Both base metal and weld metal are of significance and are being investigated.

Strain rate effects are best characterized by comparison to quasi-static tensile, stress-strain results expressed as true stressstrain curves. To support the INL's moderate strain rate research, considerable quasi-static tensile testing has been recently conducted. This testing has resulted in a significant amount of basic material data recorded as engineering stressstrain and converted to true stress-strain relationships. Tensile testing in accordance with ASTM procedure A 370-03a [1] was conducted on dual-stamped 304/304L and 316/316L stainless steel plate materials (hereafter referred to as $304 \mathrm{~L}$ and $316 \mathrm{~L}$ ) at

\footnotetext{
${ }^{1}$ Work supported by the U. S. Department of Energy, Office of Environmental Management (National Spent Nuclear Fuel Program at the Idaho National Laboratory) under DOE Operations Office Contract No. DE-AC07-05ID14517.
} 
temperatures ranging from $-20^{\circ} \mathrm{F}$ to $600^{\circ} \mathrm{F}$. Two plate thicknesses, eight material heats, and both base and weld metal were investigated.

Although $304 \mathrm{~L}$ and $316 \mathrm{~L}$ stainless steel materials have been studied for many years and by numerous investigators [25], relatively little recent, typical data reflecting current commercial chemical compositions and dual-stamping is readily available to practitioners. Even less data expressed as true stress-strain relationships to failure can be found in the literature. The purpose of this paper is to present some typical results of quasi-static tensile testing of $304 \mathrm{~L}$ and $316 \mathrm{~L}$ stainless steels in order to add to the existing data pool for these materials and make the data more readily available to other researchers, engineers, and interested parties. Typical stressstrain values are often of interest for failure analyses and integrity evaluations associated with low probability, extreme loading conditions. A comparison to ASME Code minimums is also made.

\section{MATERIALS AND SPECIMEN PREPARATION}

Two commercial, readily available, dual-stamped stainlesssteel alloys, 304L and 316L, were tested in this study. The alloys were procured from various manufacturers as 48 -inch by 120-inch plate material satisfying the ASME SA-240 standard specification [6]. Both alloys were purchased from four different heats and in two different thicknesses, 1/4-inch and-1/2 inch. Plate thickness was a functional requirement for dynamic strain rate specimens not discussed in this paper. For the purposes of this reporting, material thickness effects were assumed negligible. The as-received plate material was hot rolled, annealed, and pickled (HRAP finish). The plate's chemical composition and minimum room temperature mechanical properties as reported by the manufactures are listed in Table 1.

Base metal test specimen blanks were cut from the asreceived plate with the longitudinal axis of the specimens parallel to the rolling direction of the plate. Standard, round 0.350 inch diameter test specimens were machined from the $1 / 2$ inch thick plate blanks to the dimensions specified in ASTM
A370-03a as shown in Fig. 1.

Specimen blanks from the $1 / 4$-inch thick plate were also machined into round 0.160 -inch diameter specimens proportional in size to the standard specimen. The ends of the specimens outside of the gage length were threaded to match the holders on the tensile test machine. Specimens were not further treated following machining.

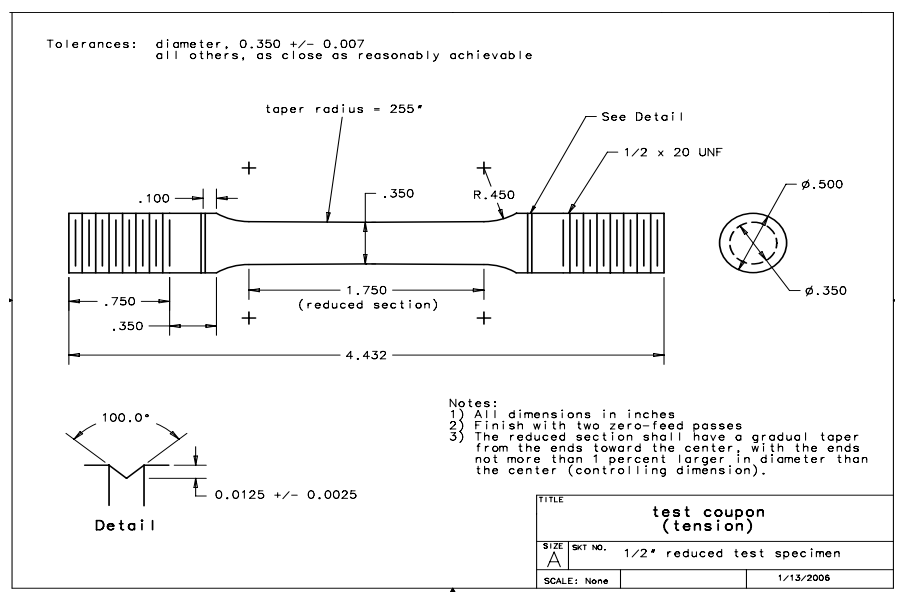

Figure 1. Standard, Round 0.350-inch Diameter Specimen

The weld test specimen blanks were prepared by first welding two pieces of longitudinally cut as-received plate material together and then cutting the specimen blanks centered on the axis of the weld. Using a gas tungsten arc welding process, a full penetration groove weld was completed with welding from both sides. The weld was designed to result in a region of welded material sufficient to produce a machined test specimen of full weld material in the gage region. All welds were radiographed prior to acceptance. Welded test specimens were machined to the same geometry and dimensions as the base metal specimens.

\section{TEST PROCEDURE}

Conventional quasi-static tensile tests were performed at room temperature $\left(\approx 70^{\circ} \mathrm{F}\right),-20^{\circ} \mathrm{F}, 300^{\circ} \mathrm{F}$, and $600^{\circ} \mathrm{F}$ using an

Table 1. As-Received Chemical Composition and Reported Minimum Mechanical Properties

\begin{tabular}{|c|c|c|c|c|c|c|c|c|c|c|c|c|c|}
\hline \multirow[b]{2}{*}{ Heat } & \multicolumn{10}{|c|}{ Chemical Composition, \% } & \multicolumn{3}{|c|}{ Properties } \\
\hline & C & CR & $\mathrm{CU}$ & $\mathrm{MN}$ & MO & $\mathrm{N}$ & $\mathrm{NI}$ & $P$ & $\mathrm{~S}$ & SI & $\begin{array}{c}\text { UTS } \\
\text { ksi }\end{array}$ & $\begin{array}{c}.2 \% \text { YS } \\
\mathrm{ksi}\end{array}$ & $\begin{array}{l}\text { Elong. } \\
\%-2 \text { in. }\end{array}$ \\
\hline \multicolumn{14}{|l|}{$\overline{304 L}$} \\
\hline$\overline{72 \mathrm{~K} 9}$ & 2.026 & 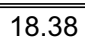 & 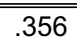 & $\overline{c 1.784}$ & 2.300 & 2.071 & 8.187 & 2.028 & 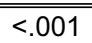 & .501 & 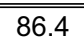 & 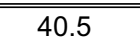 & $\overline{c 60.9}$ \\
\hline $54 \mathrm{M} 7$ & .021 & 18.29 & .361 & 1.833 & .308 & .063 & 8.325 & .031 & .004 & .474 & 84.9 & 39.3 & 60.9 \\
\hline 485896 & .028 & 18.02 & .210 & 1.640 & .200 & .057 & 8.250 & .030 & .001 & .330 & 98.0 & 46.0 & 51.0 \\
\hline 64A1 & .025 & 18.16 & .341 & 1.757 & .331 & .057 & 8.305 & .030 & .006 & .275 & 90.3 & 44.5 & 52.2 \\
\hline \multicolumn{14}{|l|}{$316 \mathrm{~L}$} \\
\hline 230468 & (.022 & 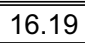 & 230 & 2.9200 & 2.130 & (.016 & 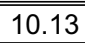 & 2.023 & 2.003 & .620 & 82.5 & $4 \overline{c 40.8}$ & 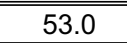 \\
\hline $67 \mathrm{~K} 0$ & .029 & 16.97 & .346 & 1.549 & 2.174 & .058 & 10.32 & .028 & .001 & .465 & 83.9 & 40.9 & 56.3 \\
\hline 48R8 & .026 & 16.89 & 380 & 1.641 & 2.148 & .045 & 10.25 & .026 & .001 & .271 & 86.2 & 48.4 & 45.9 \\
\hline $76 \mathrm{H} 3$ & .023 & 16.91 & .291 & 1.589 & 2.179 & .050 & 10.16 & .028 & .002 & .249 & 82.8 & 44.9 & 49.4 \\
\hline
\end{tabular}


Instron Model 4505 universal testing machine with a maximum capacity of 22,000 lb. Specimens were gripped in threaded connectors, aligned using pins and clevises, and loaded by crosshead displacement at a rate of 0.0394 inches/minute. Force-displacement output was continuously recorded to specimen failure. LabVIEW 7.0 [7] software was used to record and display the specimen temperature, forcedisplacement and engineering stress-strain data, and write the data to an Excel file for later evaluation.

An electric furnace was used to heat the specimens while a nitrogen-cooled cold box was used for cooling. Because of the small size of the test specimens, methods of preheating, precooling and holding the specimens at temperature were not employed. Thermocouples were attached to the temperature specimens at the gage length top, center, and bottom positions to monitor specimen temperature before and during the tests. Furnace and cold box temperatures where controlled so that variations in temperature over the specimen gage length did not exceed $10^{\circ} \mathrm{F}$ Specimen temperature during the test was controlled within $\pm 10^{\circ} \mathrm{F}$ of the desired test temperature. For the room temperature and $-20^{\circ} \mathrm{F}$ tests, displacements were measured over the specimen gage length using an extensometer. Two coupled, vertical rods, one on each side of the specimen and attached to the upper specimen holder, transferred the deformation in the gage length to an

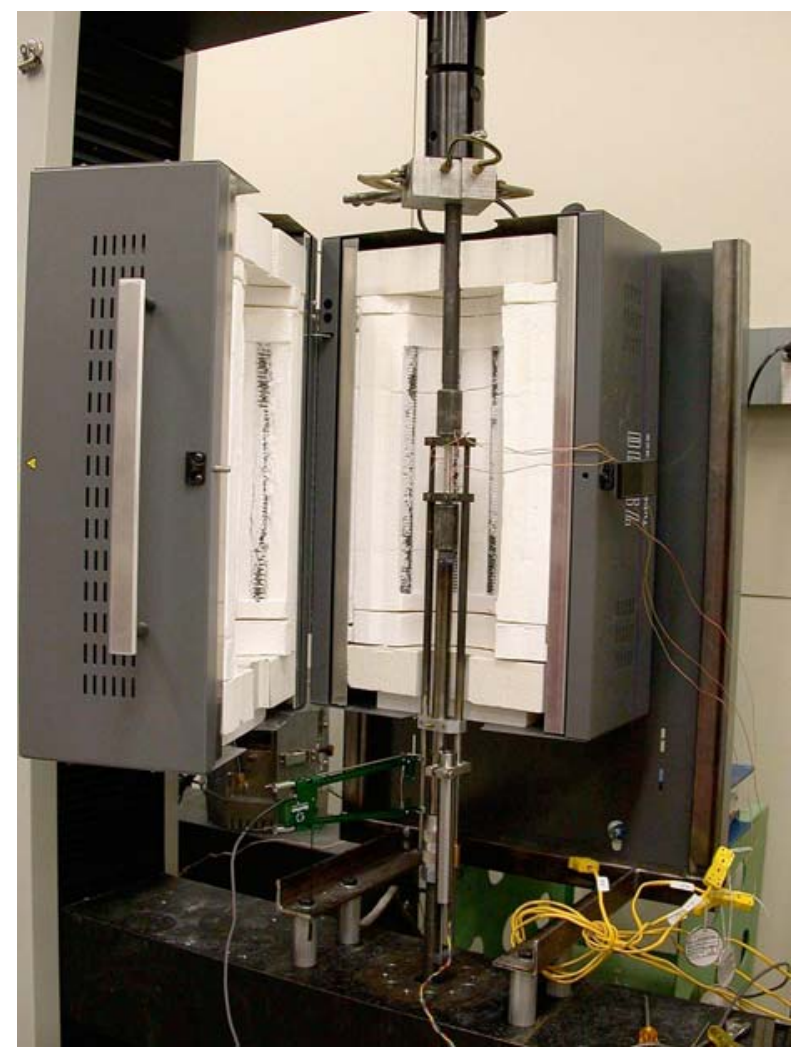

Figure 2. Specimen Setup in Furnace extensometer and linear variable displacement transducer (LVDT) located outside of the furnace for the $300^{\circ} \mathrm{F}$ and $600^{\circ} \mathrm{F}$ tests. The hot tensile test setup is shown in Fig. 2 with the furnace open to show the specimen with transfer rods, extensometer, and LVDT.

\section{RESULTS AND DISCUSSION}

For the test sequence, a total of 144 specimens were tensile tested to failure with specimen 'necking' occurring at the engineering maximum strength followed shortly by fracture of the specimen. As the neck progressed to failure, non-uniform geometry altered the uniaxial stress state to a complex one involving shear components as well as normal stresses. Specimens typically failed in a combination of shear and tensile 'cup and cone' geometry characteristic of ductile materials and illustrated in Fig. 3.

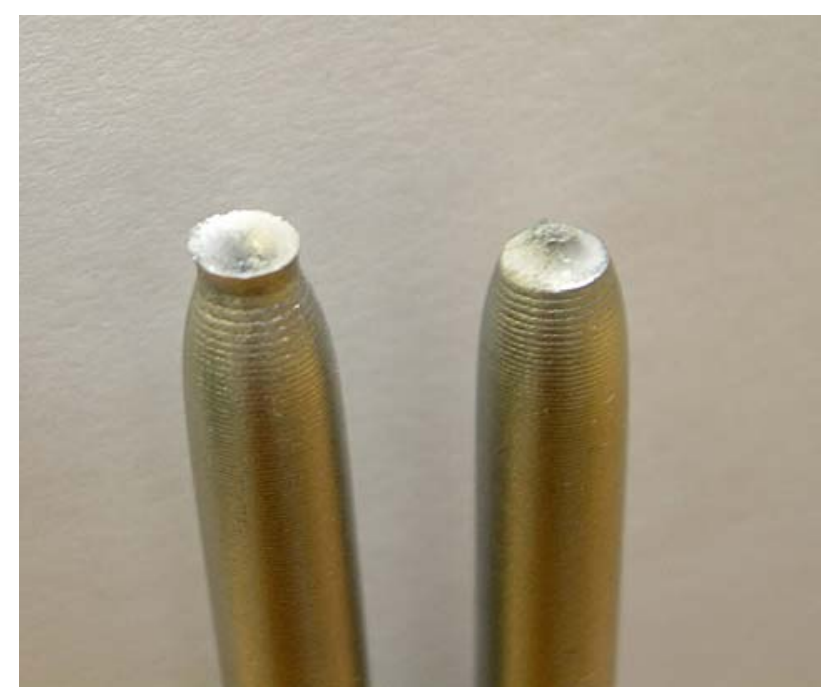

Figure 3. 'Cup and Cone' Type Failure

Material yield strength, ultimate strength, ultimate strain, fracture strength, fracture strain, area reduction, and engineering and true stress-strain curves to failure were developed from the specimen tensile test force-displacement data using standard methods. Results are summarized in Table 2 for both the 304L and 316L base and weld material. Because of the small number of tests performed (three) for each individual material type, heat, and temperature, no statistical analyses were employed and the results shown are considered typical.

True fracture strength $\left(\tilde{\sigma}_{f}\right)$ was obtained simply from the load at fracture $\left(\mathrm{P}_{\mathrm{f}}\right)$ and the final area $\left(\mathrm{A}_{\mathrm{f}}\right)$ measured at the point of fracture $\left(\tilde{\sigma}_{\mathrm{f}}=\mathrm{P}_{\mathrm{f}} / \mathrm{A}_{\mathrm{f}}\right)$. The corresponding true fracture strain $\left(\tilde{\varepsilon}_{\mathrm{f}}\right)$ was also obtained from the final area using the initial area $\left(\mathrm{A}_{\mathrm{i}}, \tilde{\varepsilon}_{\mathrm{f}}=\ln \left[\mathrm{A}_{\mathrm{i}} / \mathrm{A}_{\mathrm{f}}\right]\right)$. The neck strain $\left(\tilde{\varepsilon}_{\mathrm{n}}\right)$ is the true strain at the start of specimen necking and was obtained from the engineering ultimate strain $\left(\varepsilon_{\mathrm{e}}\right)$ corresponding to the point of ultimate strength $\left(\tilde{\varepsilon}_{\mathrm{n}}=\ln \left[1+\varepsilon_{\mathrm{e}}\right]\right)$. Reduction in area 
Table 2. Summary of Test Results for 304L and 316L Material

\begin{tabular}{|c|c|c|c|c|c|c|c|c|c|}
\hline \multicolumn{10}{|c|}{ 304L Base Metal } \\
\hline \multirow[b]{2}{*}{ Heat } & \multirow[b]{2}{*}{ Temp. } & \multicolumn{4}{|c|}{ True } & \multicolumn{4}{|c|}{ Engineering } \\
\hline & & $\begin{array}{l}\text { Fracture } \\
\text { Strength }\end{array}$ & $\begin{array}{c}\text { Fracture } \\
\text { Strain }\end{array}$ & $\begin{array}{l}\text { Neck } \\
\text { Strain }\end{array}$ & $\begin{array}{c}\text { Reduction } \\
\text { in Area }\end{array}$ & $\begin{array}{l}\text { Ultimate } \\
\text { Strength }\end{array}$ & $\begin{array}{c}\text { Ultimate } \\
\text { Strain }\end{array}$ & $\begin{array}{c}\text { Yield } \\
\text { Strength }\end{array}$ & $\begin{array}{l}\text { Total } \\
\text { Strain }\end{array}$ \\
\hline \# & $\left({ }^{\circ} \mathrm{F}\right)$ & (ksi) & (in/in) & (in/in) & (\%) & (ksi) & (in/in) & (ksi) & (in/in) \\
\hline \multirow{4}{*}{$72 \mathrm{~K} 9$} & -20 & 329 & 1.426 & 0.36 & 76 & 140.0 & 0.442 & 51.1 & 0.573 \\
\hline & 70 & 333 & 1.648 & 0.50 & 81 & 95.7 & 0.642 & 40.2 & 0.763 \\
\hline & 300 & 195 & 1.620 & 0.31 & 80 & 73.1 & 0.369 & 30.4 & 0.487 \\
\hline & 600 & 183 & 1.616 & 0.28 & 80 & 67.6 & 0.319 & 22.7 & 0.403 \\
\hline \multirow{4}{*}{$54 \mathrm{M} 7$} & -20 & 392 & 1.714 & 0.36 & 82 & 134.9 & 0.437 & 47.9 & 0.579 \\
\hline & 70 & 277 & 1.687 & 0.48 & 81 & 95.7 & 0.616 & 39.2 & 0.762 \\
\hline & 300 & 255 & 1.900 & 0.32 & 85 & 69.4 & 0.385 & 24.3 & 0.502 \\
\hline & 600 & 212 & 1.721 & 0.29 & 82 & 65.1 & 0.344 & 22.3 & 0.435 \\
\hline \multirow{4}{*}{485896} & -20 & 376 & 1.637 & 0.38 & 81 & 140.7 & 0.468 & 46.5 & 0.585 \\
\hline & 70 & 352 & 2.017 & 0.46 & 87 & 96.0 & 0.584 & 44.3 & 0.711 \\
\hline & 300 & 257 & 1.929 & 0.30 & 85 & 73.5 & 0.35 & 31.5 & 0.493 \\
\hline & 600 & 270 & 1.833 & 0.25 & 84 & 69.3 & 0.289 & 32.5 & 0.385 \\
\hline \multirow{4}{*}{$64 \mathrm{~A} 1$} & -20 & 383 & 1.666 & 0.44 & 81 & 136 & 0.542 & 46.2 & 0.677 \\
\hline & 70 & 334 & 1.814 & 0.52 & 84 & 97.3 & 0.691 & 37.8 & 0.818 \\
\hline & 300 & 235 & 1.778 & 0.31 & 83 & 70.0 & 0.374 & 20.9 & 0.502 \\
\hline & 600 & 187 & 1.540 & 0.29 & 79 & 65.8 & 0.332 & 24.1 & 0.432 \\
\hline \multicolumn{10}{|c|}{ 304L Weld Metal } \\
\hline \multirow{4}{*}{ 54M7 } & -20 & 305 & 1.398 & 0.38 & 75 & 118.2 & 0.472 & 65.2 & 0.597 \\
\hline & 70 & 266 & 1.450 & 0.37 & 77 & 94.5 & 0.445 & 60.7 & 0.603 \\
\hline & 300 & 189 & 1.386 & 0.25 & 75 & 72.7 & 0.288 & 48.5 & 0.43 \\
\hline & 600 & 142 & 1.037 & 0.24 & 65 & 68.2 & 0.282 & 42.7 & 0.388 \\
\hline \multirow{4}{*}{485896} & -20 & 346 & 1.526 & 0.47 & 78 & 114.0 & 0.604 & 48.0 & 0.704 \\
\hline & 70 & 295 & 1.585 & 0.39 & 79 & 88.3 & 0.484 & 35.9 & 0.602 \\
\hline & 300 & 217 & 1.695 & 0.21 & 82 & 66.6 & 0.232 & 43.2 & 0.348 \\
\hline & 600 & 204 & 1.585 & 0.23 & 79 & 63.8 & 0.263 & 26.0 & 0.347 \\
\hline \multicolumn{10}{|c|}{ 316L Base Metal } \\
\hline \multirow{4}{*}{230468} & -20 & 346 & 1.760 & 0.40 & 83 & 114.7 & 0.498 & 38.8 & 0.652 \\
\hline & 70 & 342 & 2.080 & 0.46 & 88 & 82.4 & 0.591 & 28.9 & 0.751 \\
\hline & 300 & 236 & 1.853 & 0.30 & 84 & 68.7 & 0.356 & 25.5 & 0.47 \\
\hline & 600 & 235 & 1.762 & 0.28 & 83 & 64.3 & 0.316 & 21.7 & 0.413 \\
\hline \multirow{4}{*}{$67 \mathrm{~K} 0$} & -20 & 362 & 1.697 & 0.43 & 82 & 113.0 & 0.536 & 52.9 & 0.699 \\
\hline & 70 & 232 & 1.486 & 0.44 & 77 & 89.2 & 0.437 & 41.6 & 0.591 \\
\hline & 300 & 220 & 1.644 & 0.27 & 81 & 74.8 & 0.304 & 37.1 & 0.416 \\
\hline & 600 & 191 & 1.427 & 0.25 & 76 & 72.0 & 0.287 & 28.3 & 0.375 \\
\hline \multirow{4}{*}{$48 \mathrm{R} 8$} & -20 & 402 & 2.054 & 0.51 & 87 & 113.2 & 0.637 & 50.3 & 0.794 \\
\hline & 70 & 348 & 2.112 & 0.46 & 88 & 93.6 & 0.585 & 37.7 & 0.766 \\
\hline & 300 & 346 & 2.235 & 0.28 & 89 & 74.7 & 0.326 & 23.3 & 0.459 \\
\hline & 600 & 310 & 2.032 & 0.27 & 87 & 68.4 & 0.316 & 26.4 & 0.410 \\
\hline \multirow{4}{*}{$76 \mathrm{H} 3$} & -20 & 360 & 1.845 & 0.52 & 84 & 113.0 & 0.682 & 50.7 & 0.844 \\
\hline & 70 & 388 & 2.089 & 0.48 & 88 & 92.8 & 0.616 & 41.6 & 0.782 \\
\hline & 300 & 230 & 1.736 & 0.31 & 82 & 70.4 & 0.366 & 33.6 & 0.506 \\
\hline & 600 & 212 & 1.637 & 0.27 & 81 & 68.1 & 0.313 & 21.2 & 0.410 \\
\hline 316L W & Ietal & & & & & & & & \\
\hline & -20 & 300 & 1.498 & 0.37 & 78 & 101.9 & 0.448 & 59.9 & 0.629 \\
\hline 230460 & 70 & 226 & 1.308 & 0.35 & 73 & 86.9 & 0.417 & 56.3 & 0.563 \\
\hline 230468 & 300 & 165 & 1.238 & 0.25 & 71 & 71.4 & 0.280 & 43.4 & 0.405 \\
\hline & 600 & 140 & 1.045 & 0.24 & 65 & 66.6 & 0.259 & 30.3 & 0.375 \\
\hline & -20 & 411 & 1.802 & 0.42 & 83 & 97.4 & 0.530 & 42.5 & 0.627 \\
\hline $48 \mathrm{R} 8$ & 70 & 266 & 1.646 & 0.40 & 81 & 78.9 & 0.484 & 37.7 & 0.624 \\
\hline & 300 & 227 & 1.749 & 0.25 & 83 & 69.3 & 0.294 & 24.5 & 0.410 \\
\hline & 600 & 186 & 1.512 & 0.24 & 78 & 63.3 & 0.268 & 18.2 & 0.358 \\
\hline
\end{tabular}

\section{$1 / 2$-inch specimens shown shaded}


(RA), how much the specimen necked or reduced in diameter at the point of fracture, is a measure of ductility related to the fracture strain $\left(\tilde{\varepsilon}_{\mathrm{f}}=\ln [100 /\{100-\% \mathrm{RA}\}]\right)$. Engineering ultimate strength and strain correspond to the peak stress on the engineering stress-strain curve. The $0.2 \%$ strain offset method was used to determine the material yield strength from the engineering stress-strain curve. Because the tensile testing was focused on development of continuous engineering stressstrain curves to failure, at the sacrifice of an accurate yield point definition, many of the resulting curves did not display a distinct modulus. In accordance with the recommendations of ASTM A 370-03a, an appropriate modulus value was assumed based on Part D of the ASME Code [8].

In general, the largest variations in mechanical properties between the specimens tested occurred in the yield and fracture strengths, the $316 \mathrm{~L}$ material, and for hot temperature conditions. The details of the plate fabrication processes used for the different heats are not known, and one can only assume that they are typical of commercial production. Thus, the differences in properties are considered representative of what would be observed in today's commercial products. For material types and all temperatures tested, the yield and ultimate strength test results exceeded ASME Code specified minimums.

The mechanical properties at room temperature for SA240 plate, Type 304L and 316L material, have a published minimum yield strength of $25.0 \mathrm{ksi}$, a minimum ultimate strength of $70.0 \mathrm{ksi}$, and a minimum elongation of $40 \%$ [6]. At room temperature, the yield strength of the test specimens varied from $37.8 \mathrm{ksi}$ to $44.3 \mathrm{ksi}$ for the $304 \mathrm{~L}$ material and from $28.9 \mathrm{ksi}$ to $41.6 \mathrm{ksi}$ for the $316 \mathrm{~L}$ material. The ultimate strength varied from $95.7 \mathrm{ksi}$ to $97.3 \mathrm{ksi}$ for the $304 \mathrm{~L}$ material and from $82.4 \mathrm{ksi}$ to $93.6 \mathrm{ksi}$ for the $316 \mathrm{~L}$ material. The engineering total strain, or engineering strain at fracture, varied from $71 \%$ to $82 \%$ and from $59 \%$ to $78 \%$ for the two materials respectively. Although not a direct comparison, the engineering fracture strains were well above the specified minimum elongation of $40 \%$. Measured Reduction in Area was quite high (ranging from $76 \%$ to $89 \%$ ) indicating good ductility qualities for the two material types over the entire temperature range tested.

Typical engineering and true stress-strain curves for the tested 304L and 316L materials are shown in Figs. 4 through 7. Up to the point of specimen necking, the true stress-strain curve was derived from the engineering stress-strain curve using standard relationships [9]. Once necking begins, true stress and strains may be determined using the actual specimen cross-sectional area measured at the base of the neck. The tensile testing did not include a method of continuous monitoring of the neck area. For the true stress strain curves given, values between the point of specimen necking (ultimate stress on the engineering curve) to the point of fracture were extrapolated. Also, at this reporting, no attempt has been made to incorporate a Bridgman type correction or determine the simple power relationship strainhardening exponent and strength coefficient [9].

Figures 8 through 13 and 14 through 19 show how the various reported material properties varied with temperature and heat number for the $304 \mathrm{~L}$ and $316 \mathrm{~L}$ materials, respectively. Figure 20 shows a comparison of the engineering stress-strain relationship at room temperature for a single heat of base material and corresponding weld material. As expected, the weld material response is initially stiffer with less overall ductility as indicated by the total strain at fracture. Figures 21 and 22 show comparisons of engineering and true stress-strain responses between the $304 \mathrm{~L}$ and $316 \mathrm{~L}$ material types over the full range of temperatures tested. Except for a marked difference in the curves at $-20^{\circ} \mathrm{F}$, the material responses were very similar. At $-20^{\circ} \mathrm{F}$, the $304 \mathrm{~L}$ material consistently responded with a sharp increase in strain hardening and material strength following yield (and prior to necking) producing a distinctive 'hump' in the plastic flow portion of the engineering stress-strain curve. For the most part, this phenomenon was not observed in the $316 \mathrm{~L}$ material although a small, but noticeable hump was noted for one $316 \mathrm{~L}$ base material specimen tested at $-20^{\circ} \mathrm{F}$.

Figures 23 and 24 present estimated room temperature engineering and true ASME Code minimum stress-strain curves for $304 \mathrm{~L}$ and $316 \mathrm{~L}$ material, respectively, developed from the typical test data. A simple approach was used incorporating the shape of the typical test specimen engineering stress-strain curve and the Code minimum yield strength $(25.0 \mathrm{ksi})$ and ultimate strength $(70.0 \mathrm{ksi})$. The typical engineering stress-strain curve was first reduced in stress at every point by an amount equal to the difference in typical yield strength and Code minimum yield strength and in strain by an amount equal to this difference in yield stress divide by the modulus of elasticity. A second curve was similarly generated using the difference in typical ultimate strength and Code minimum ultimate strength. The two resulting curves were then joined using a smooth blend of points starting after yield on the first curve and ending before ultimate on the second curve. The smooth-blended engineering curve is show in the figures and the corresponding true stress-strain curve was developed using standard relationships to the neck (ultimate strength point) and extrapolation to the fracture point. Fracture strength was established as the ratio of typical ultimate strength to Code minimum ultimate strength times the typical test fracture strength. Fracture strain was taken as the typical true fracture strain from the test reduced by the ultimate strength difference divided by the modulus of elasticity. 


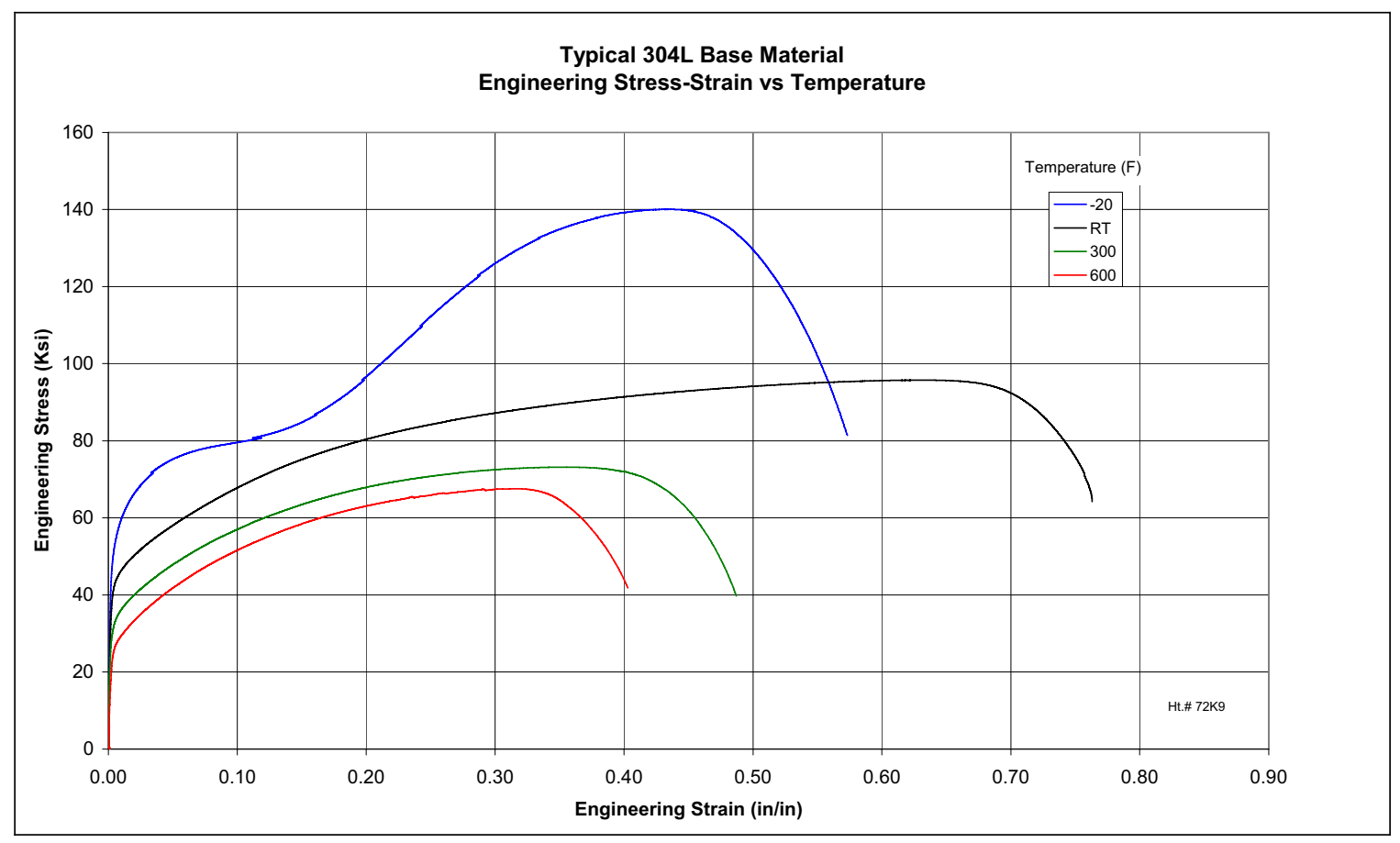

Figure 4. 304L Base Material Engineering Stress-Strain

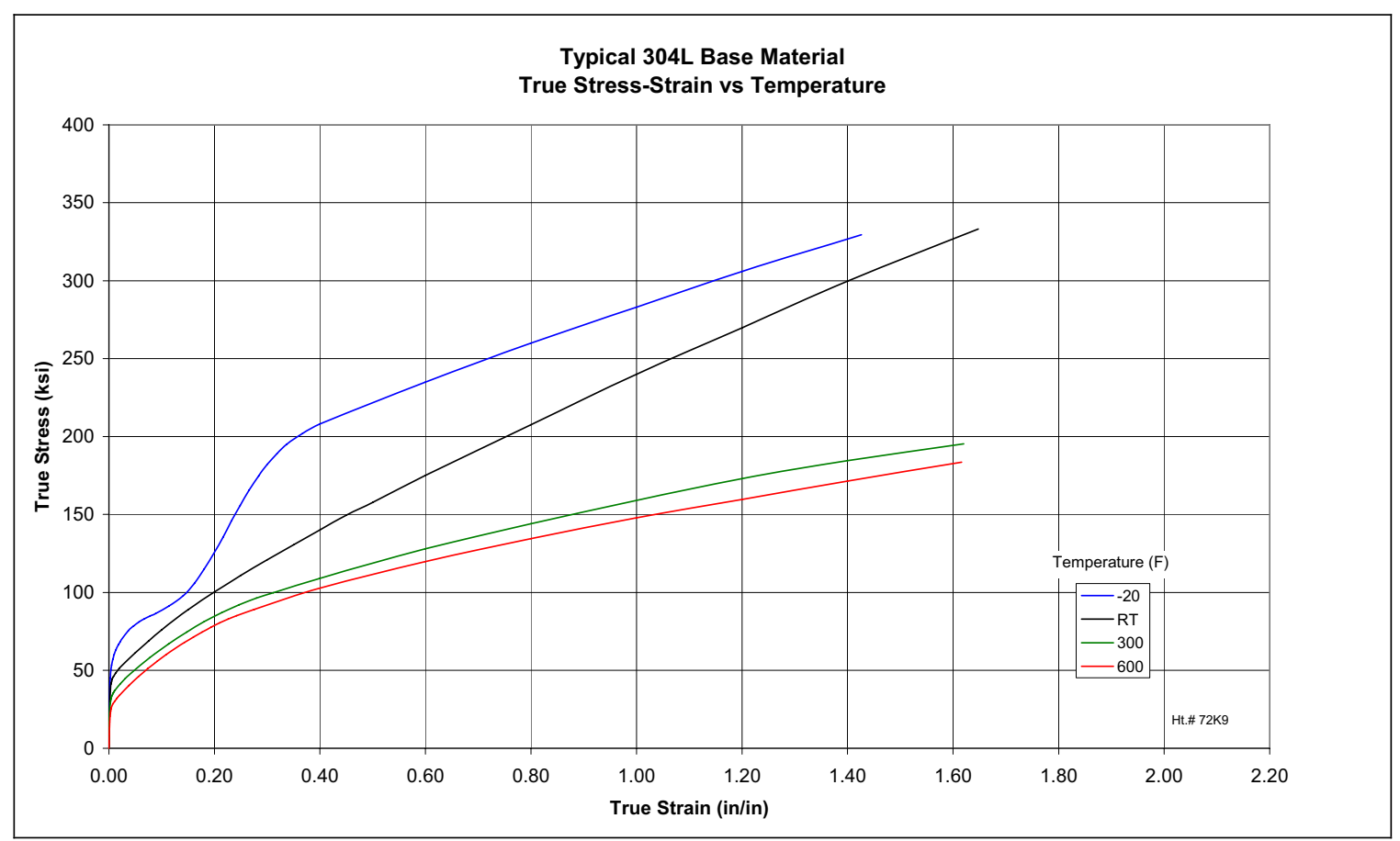

Figure 5. 304L Base Material True Stress-Strain 


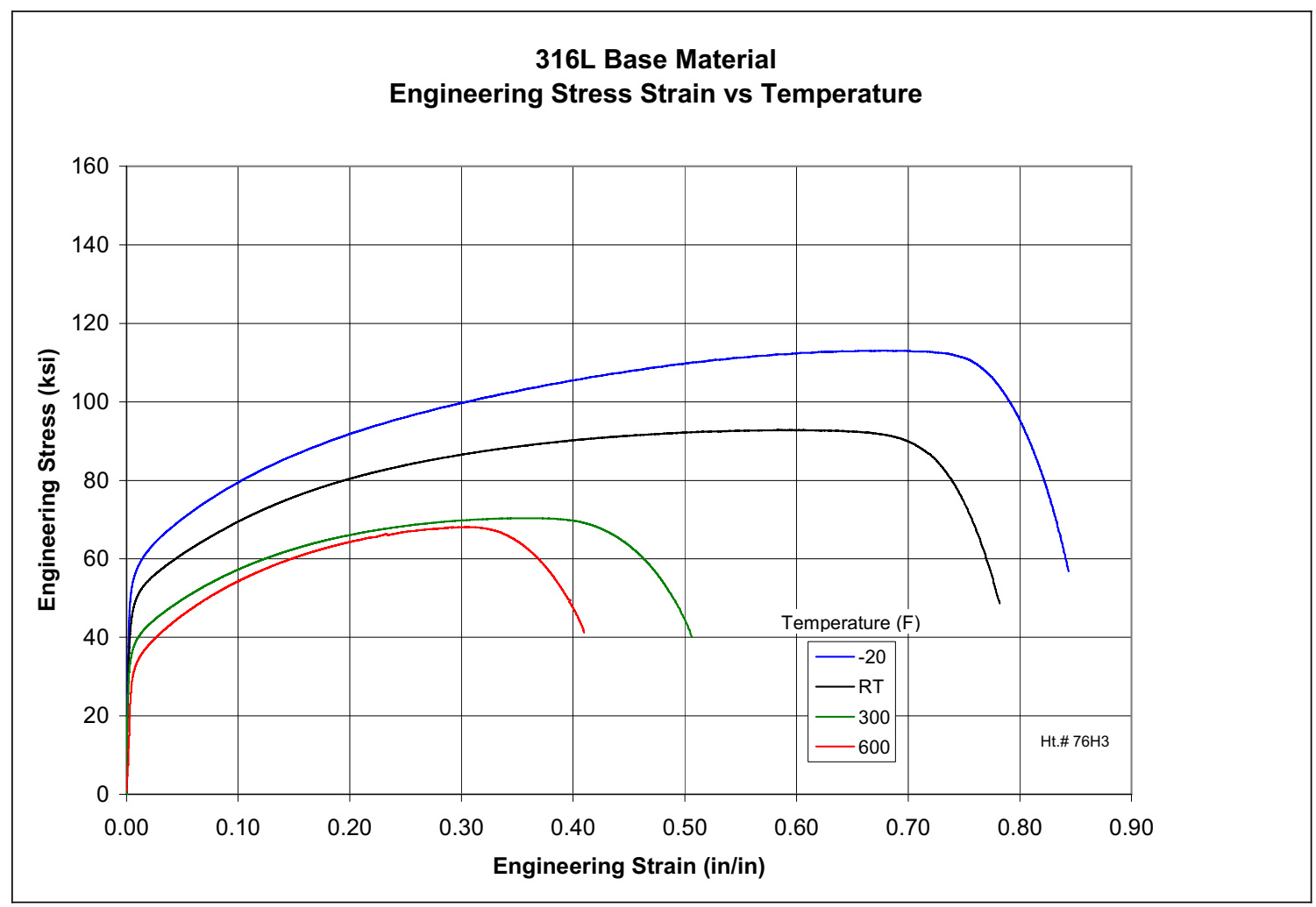

Figure 6. 316L Base Material Engineering Stress-Strain

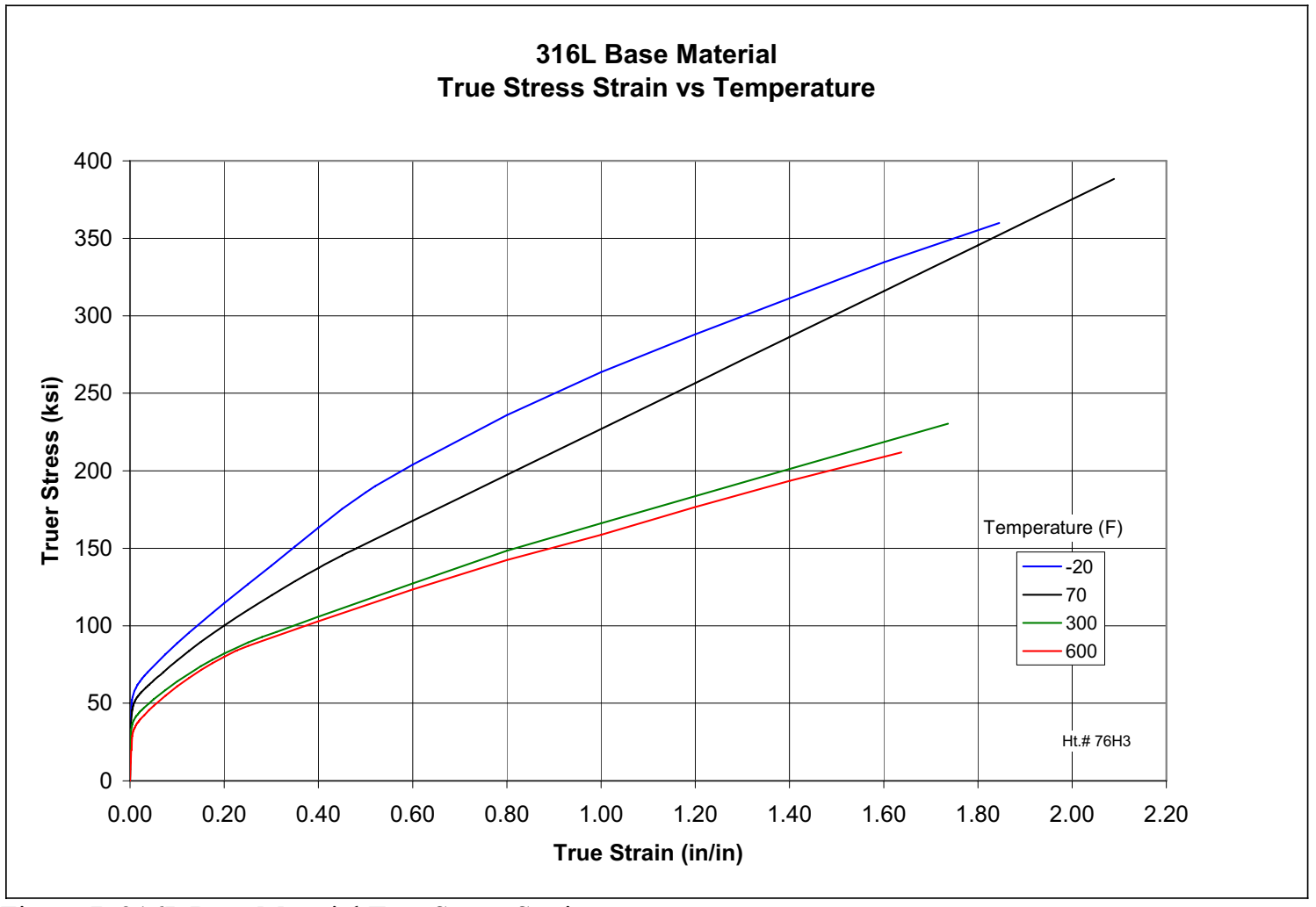

Figure 7. 316L Base Material True Stress-Strain 


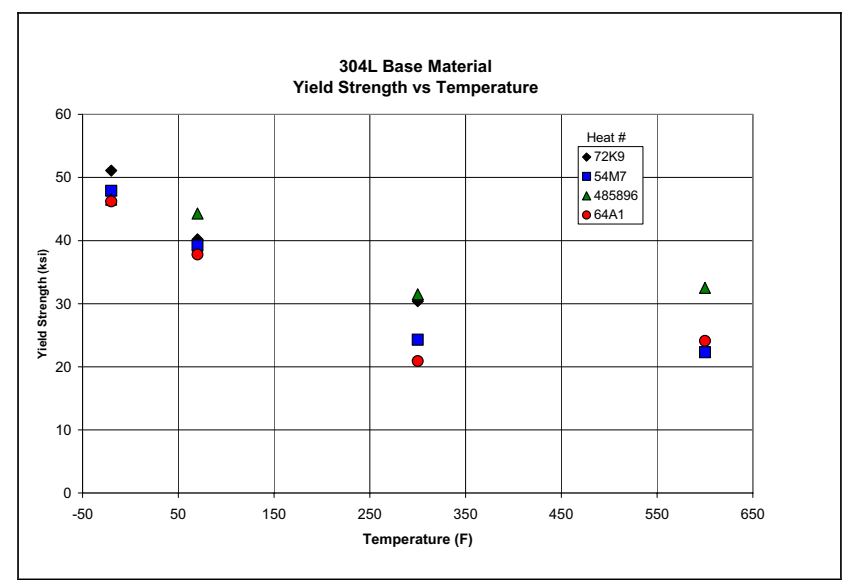

Figure 8. 304L Base Material Yield Strength

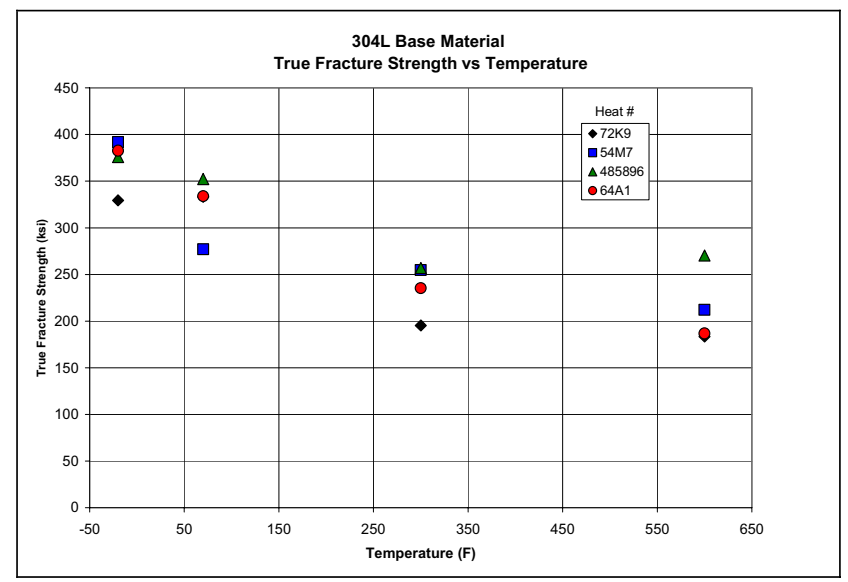

Figure 9. 304L Base Material True Fracture Strength

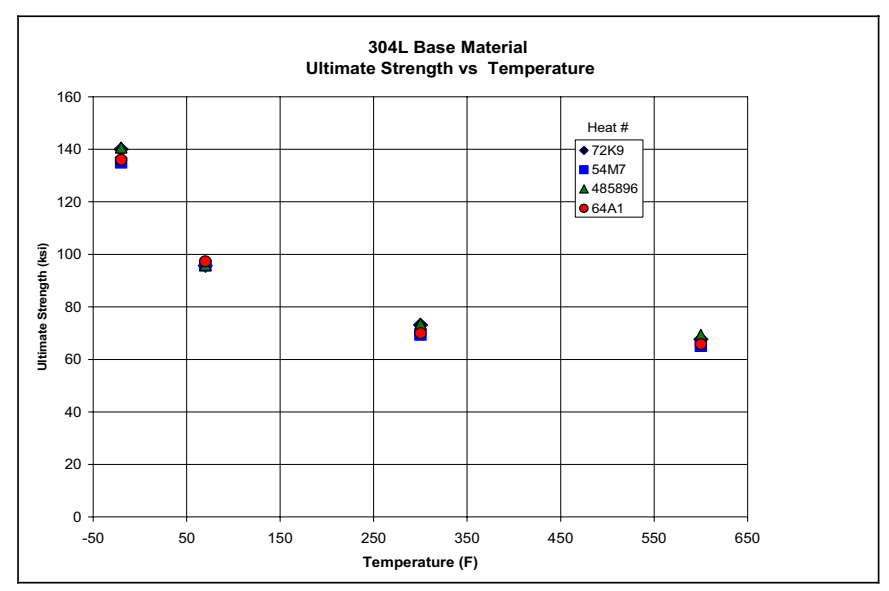

Figure 10. 304L Base Material Ultimate Strength

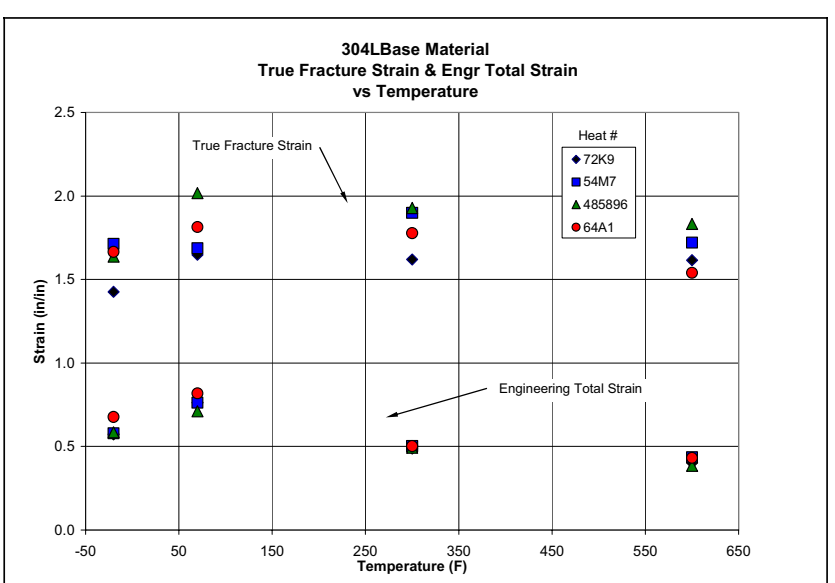

Figure 11. 304L Base Material Fracture \& Total Strain

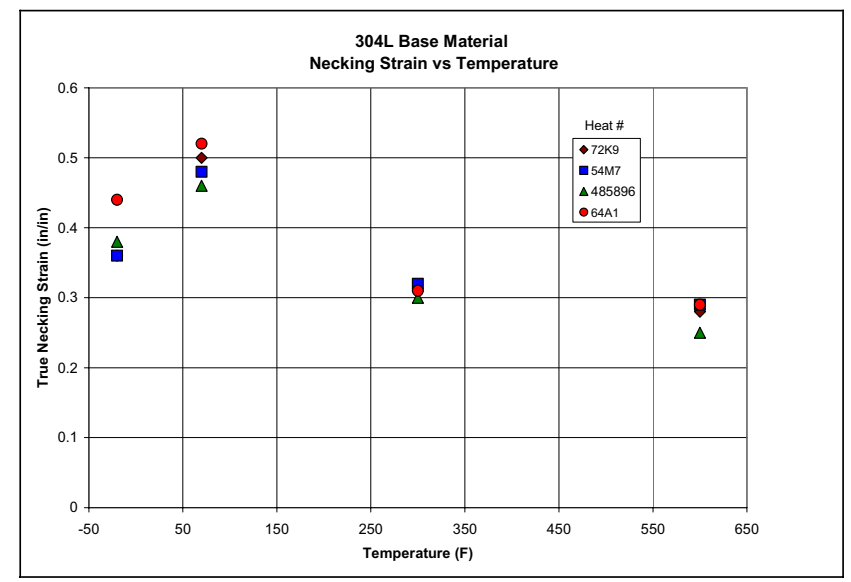

Figure 12. 304L Base Material Necking Strain

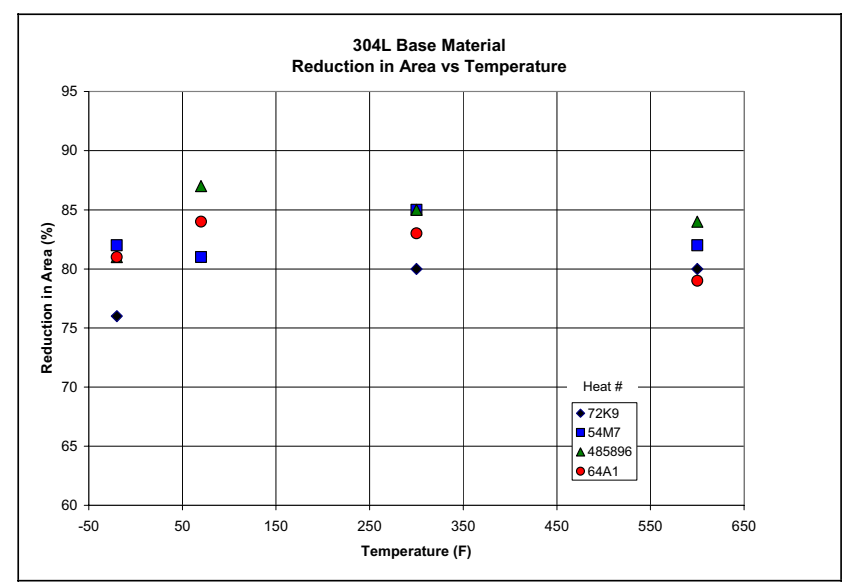

Figure 13. 304L Base Material Reduction in Area 


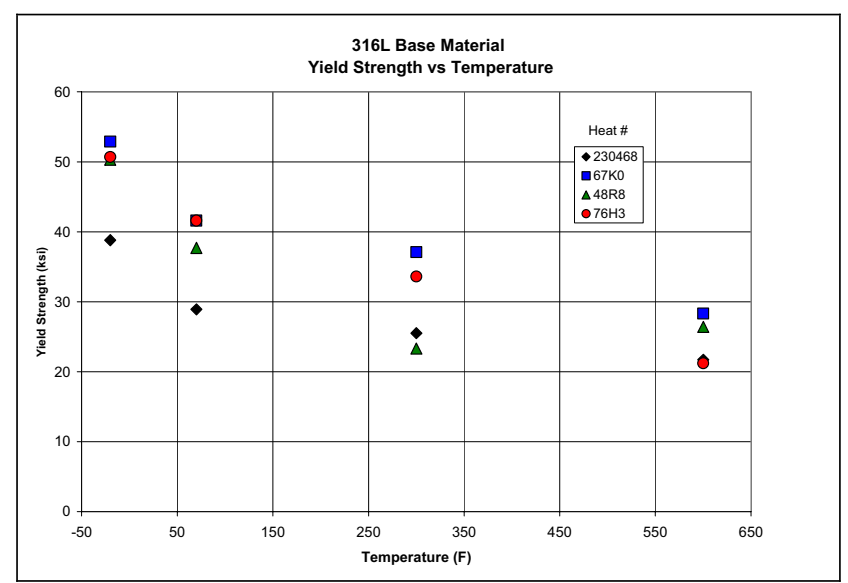

Figure 14. 316L Base Material Yield Strength

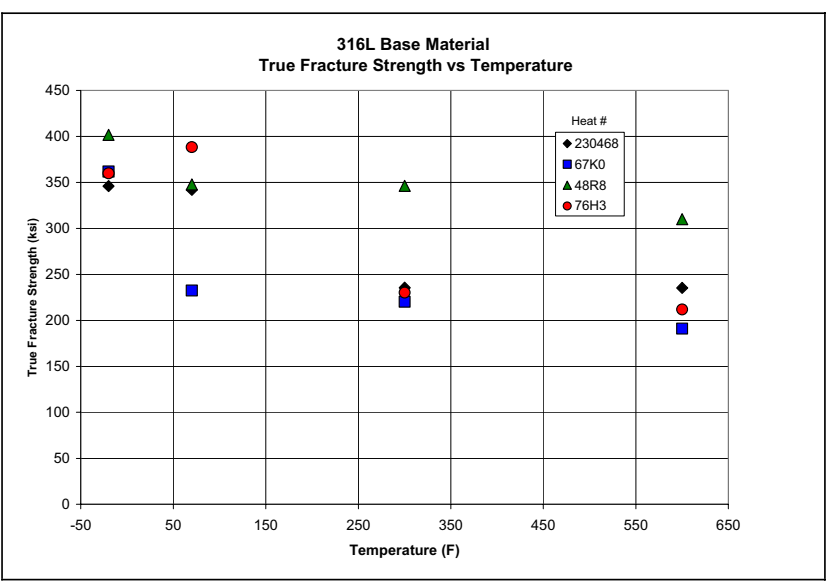

Figure 15. 316L Base Material True Fracture Strength

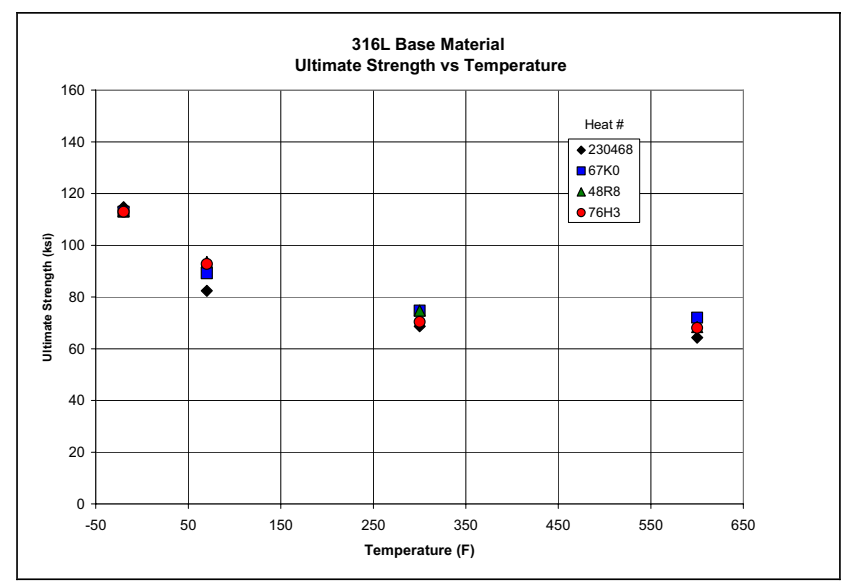

Figure 16. 316L Base Material Ultimate Strength

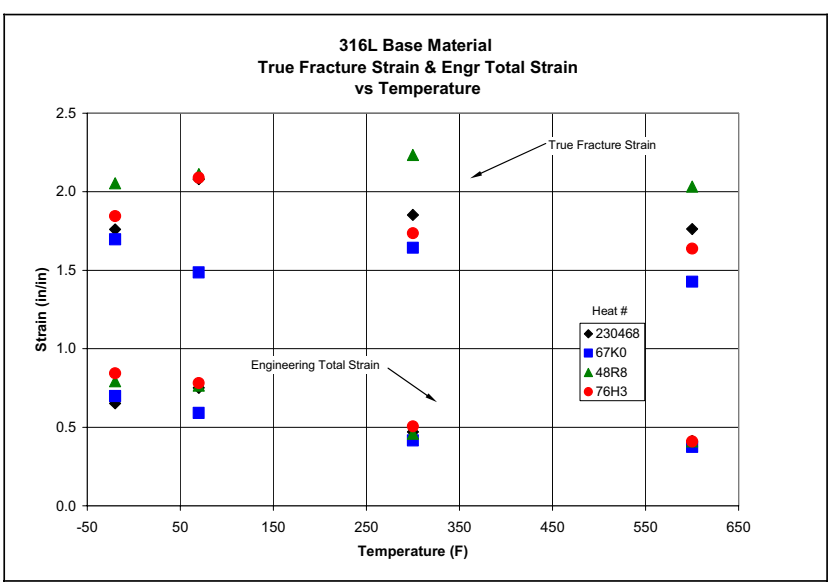

Figure 17. 316L Base Material Fracture and Total Strain

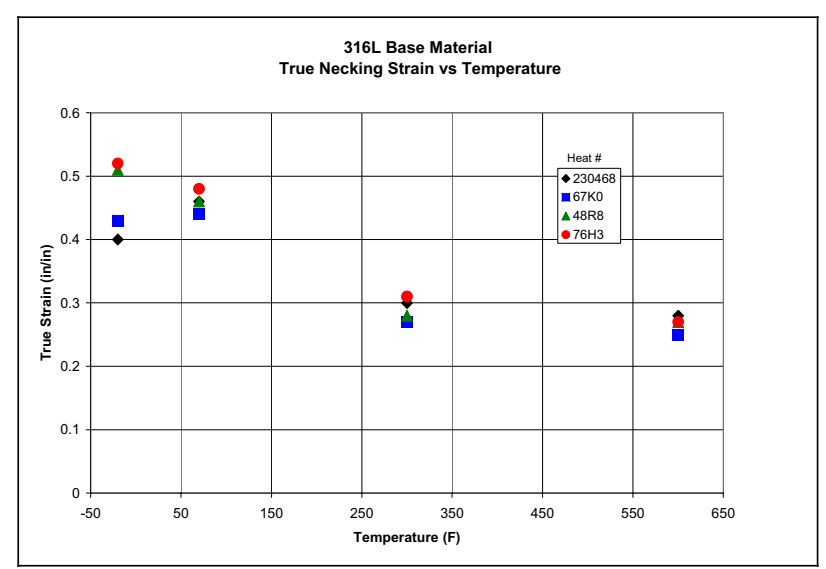

Figure 18. 316L Base Material Necking Strain

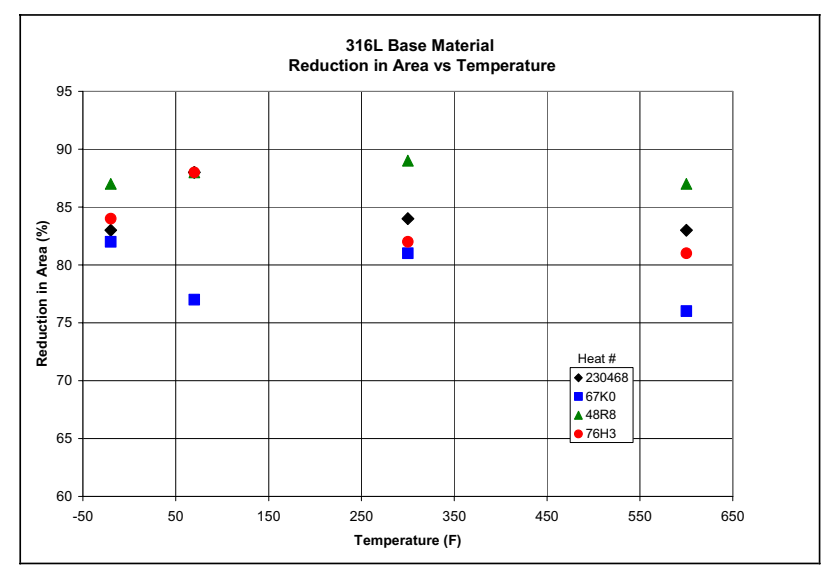

Figure 19. 316L Base Material Reduction in Area 


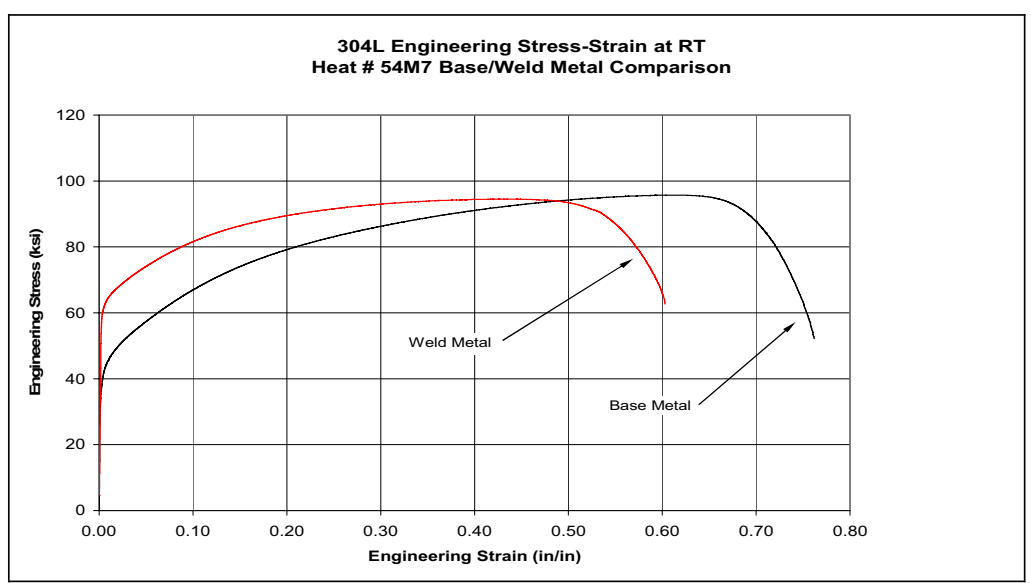

Figure 20. 304L Base and Weld Material Comparison at RT

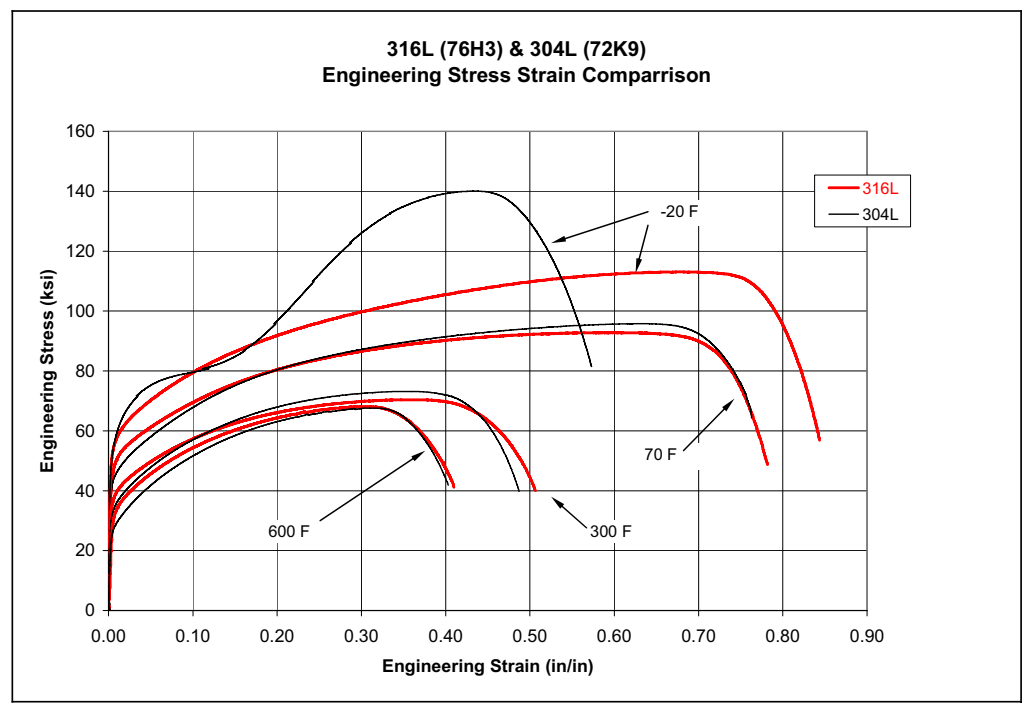

Figure 21. 304L and 316L Engineering Stress-Strain Comparison

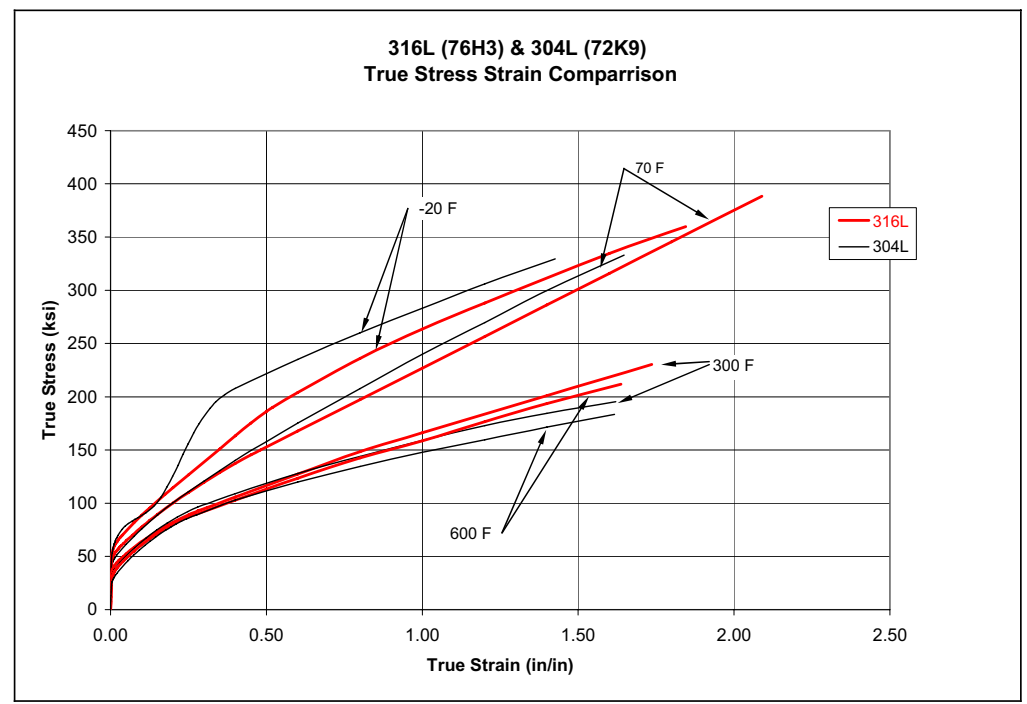

Figure 22. 304L and 316L True Stress-Strain Comparison 


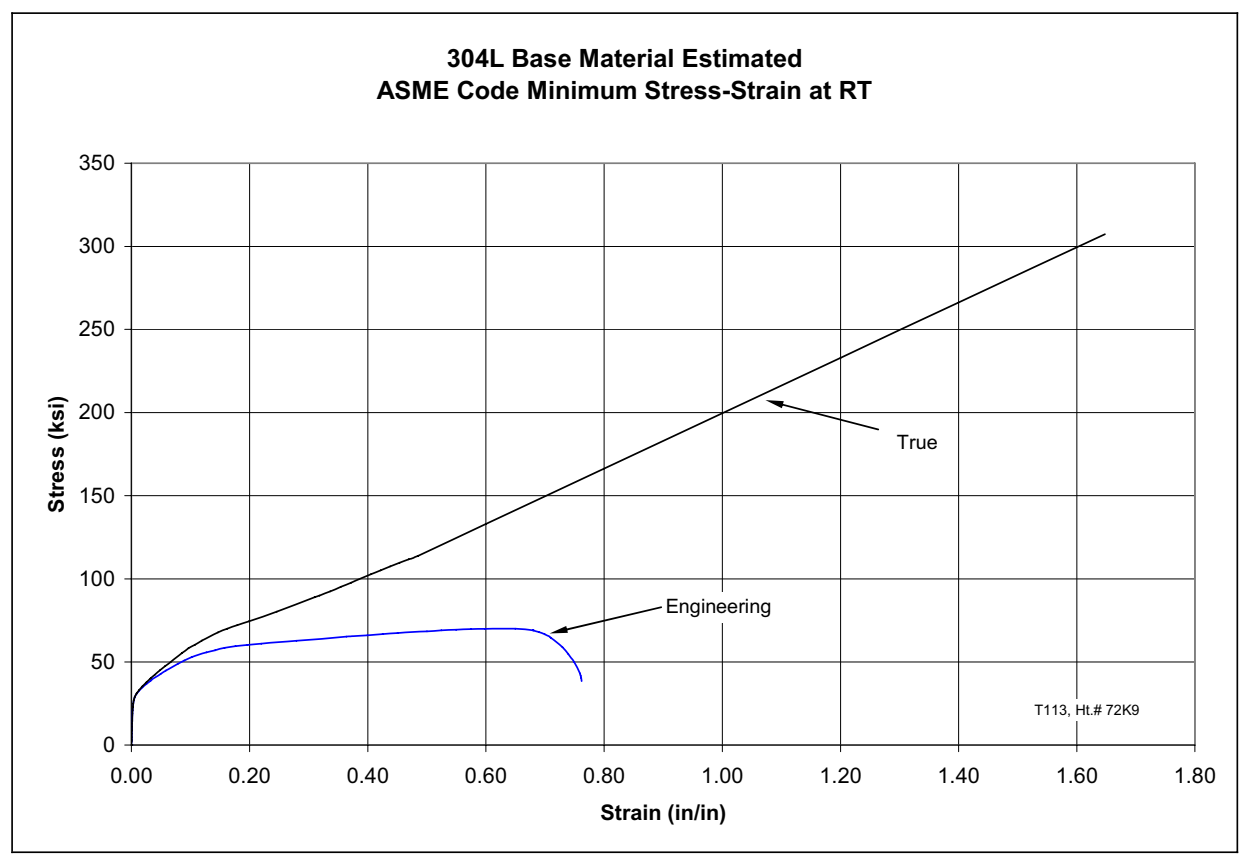

Figure 23. 304L Estimated ASME Code Minimum Stress-Strain at Room Temperature

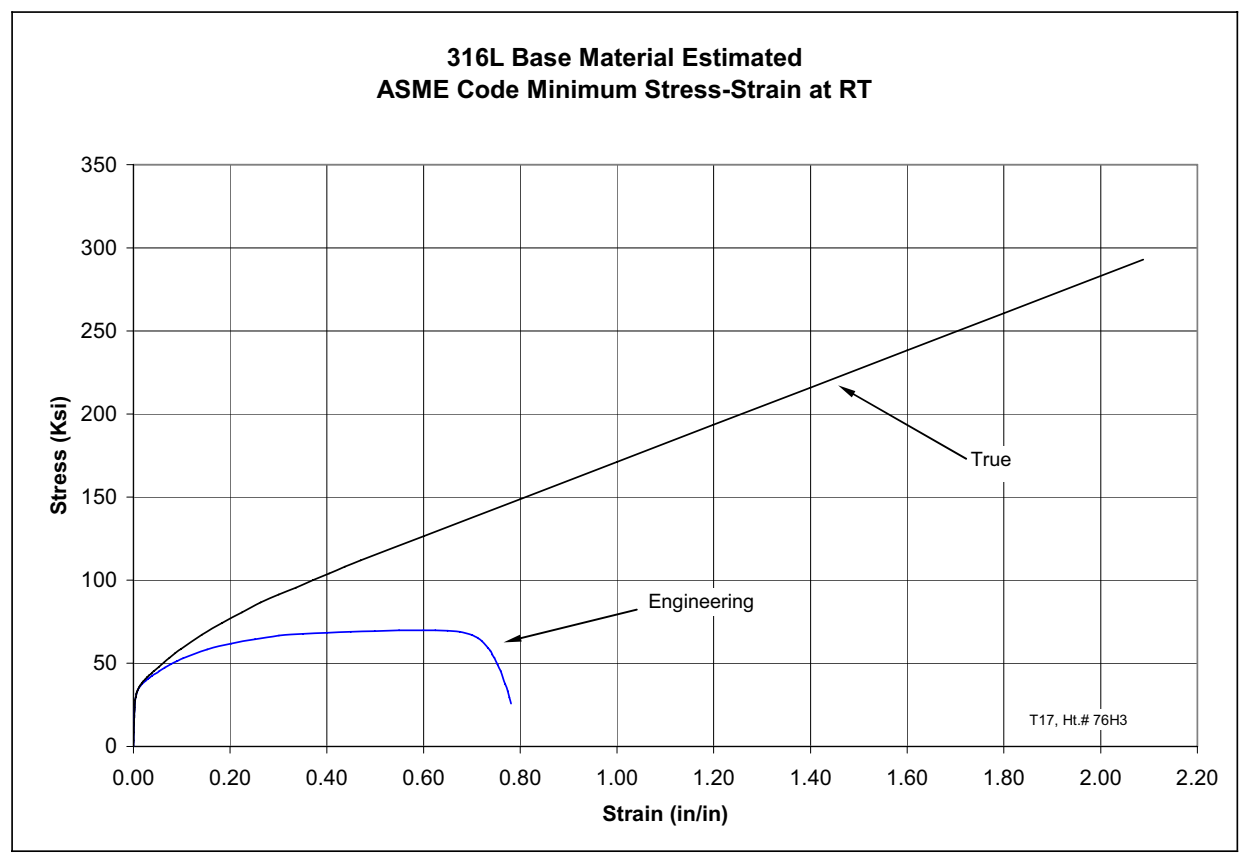

Figure 24. 316L Estimated ASME Code Minimum Stress-Strain at Room Temperature 


\section{CONCLUSIONS}

Typical static tensile test results were determined for commercially available $304 \mathrm{~L}$ and $316 \mathrm{~L}$ stainless-steel plate material over a range of temperatures from $-20^{\circ} \mathrm{F}$ to $600^{\circ} \mathrm{F}$. Engineering and true stress-strain curves to failure were developed from the test data and are suitable for performing plastic analyses where typical values are of interest. The room temperature data was adjusted to reflect published ASME Code minimum yield and ultimate strength limits and corresponding engineering and true stress-strain curves to failure were developed. These 'minimum' curves are presented for comparative purposes and do not in any way reflect actual ASME Code plastic strain limits or criterion. These estimated curves may be suitable for plastic analyses where lower bound or conservative results are of interest. For dynamic events, appropriate strain-rate effects should be addressed.

\section{ACKNOWLEDGMENTS}

The authors are indebted to the following persons for their assistance in this work: B.R. Wickham and R.J. Bitsoi for running the tensile tests, R. Lloyd for equipment calibration, and H.C. Bean for equipment calibration and quality assurance oversight.

\section{REFERENCES}

[1] ASTM A370-03a, 2003, Standard Test Methods and Definitions for Mechanical Testing of Steel Products, ASTM International, Inc., West Conshohocken, PA.

[2] McCoy, H.E., Jr., and Waddell, R.D., Mechanical Properties of Several Products from a Single Heat of Type 304 Stainless Steel, Journal of Engineering Materials and Technology, October 1975, p. 343.

[3] Simmons, W.F. and Cross, H.C., Report on the ElevatedTemperature Properties of Stainless Steels, ASTM Spec. Tech. Pub. No. 124, 1952.

[4] Conway, J.B., Stentz, R.H., and Berling, J.T., Fatigue, Tensile, and Relaxation Behavior of Stainless Steels, Technical Information Center, USAEC, 1975, p. 213.

[5] Bettis Plant Materials Manual, Westinghouse Electric Corp., Standards Engineering Section, May 1957. As published in Aerospace Structural Metals Handbook, Vol. 2, Code 1303, CINDAS/USAF CRDA Handbooks Operation, Purdue University, 1995, P. 13.

[6] American Society of Mechanical Engineers, Boiler and Pressure Vessel Code, Section II, Part A, Specification SA240/SA-240M, 2004 Edition.

[7] LabVIEW, Version 7.0, National Instruments, Inc., Austin TX.

[8] American Society of Mechanical Engineers, Boiler and Pressure Vessel Code, Section II, Part D, 2004 Edition.

[9] Dowling, N.E., 1999, Mechanical Behavior of Materials, Prentice Hall, Upper Saddle River, NJ, pp. 124-135, Chap. 4.

\section{NOTICE}

This paper was prepared as an account of work sponsored by an agency of the U. S. Government. Neither the U. S. Government nor any agency thereof, or any of their employees, makes any warranty, expressed or implied, or assumes any legal liability or responsibility for any third party's use, or the results of such use, of any information, apparatus, product or process disclosed in this report, or represents that its use by such third party would not infringe privately owned rights. The views expressed in this paper are not necessarily those of the U.S. DOE.

This material is declared a work of the U.S. Government and is not subject to copyright protection in the United States. Approved for public release; distribution is unlimited. 